\title{
Report On Complete Endpoints and Predictors of Response to Plasma Exchange - Results From a Randomized Controlled Trial in Septic Shock Patients
}

Klaus Stahl ( $\sim$ stahl.klaus@mh-hannover.de)

Medizinische Hochschule Hannover https://orcid.org/0000-0002-4833-6035

\section{Philipp Wand}

Hannover Medical School: Medizinische Hochschule Hannover

\section{Benjamin Seeliger}

Hannover Medical School: Medizinische Hochschule Hannover

Julius J. Schmidt

Hannover Medical School: Medizinische Hochschule Hannover

\section{Bernhard M.W. Schmidt}

Hannover Medical School: Medizinische Hochschule Hannover

\section{Andrea Sauer}

University Hospital Bonn: Universitatsklinikum Bonn

\section{Felix Lehmann}

University Hospital Bonn: Universitatsklinikum Bonn

\section{Ulrich Budde}

University Hospital Hamburg-Eppendorf: Universitatsklinikum Hamburg-Eppendorf

\section{Markus Busch}

Hannover Medical School: Medizinische Hochschule Hannover

\section{Olaf Wiesner}

Hannover Medical School: Medizinische Hochschule Hannover

\section{Tobias Welte}

Hannover Medical School: Medizinische Hochschule Hannover

Hermann Haller

Hannover Medical School: Medizinische Hochschule Hannover

\section{Heiner Wedemeyer}

Hannover Medical School: Medizinische Hochschule Hannover

\section{Christian Putensen}

University Hospital Bonn: Universitatsklinikum Bonn

\section{Marius M. Hoeper}

Hannover Medical School: Medizinische Hochschule Hannover 


\section{Christian Bode}

Hannover Medical School: Medizinische Hochschule Hannover

\section{Sascha David}

University Hospital Zurich: UniversitatsSpital Zurich

\section{W. Schmidt}

Hannover Medical School

\section{Research Article}

Keywords: extracorporeal treatment, plasmapheresis, endothelium, blood purification, fresh frozen plasma, sepsis, precision medicine, personalized medicine

Posted Date: November 12th, 2021

DOI: https://doi.org/10.21203/rs.3.rs-1034791/v1

License: (c) (i) This work is licensed under a Creative Commons Attribution 4.0 International License. Read Full License 


\section{Abstract}

Background: Recently, a randomized controlled trial (RCT) demonstrated rapid but individually variable hemodynamic improvement with therapeutic plasma exchange (TPE) in patients with septic shock. Prediction of clinical efficacy in specific sepsis treatments is fundamental for individualized sepsis therapy.

Methods: In the original RCT patients with septic shock of $<24 \mathrm{~h}$ duration and norepinephrine (NE) requirement $\geq 0.4 \mu \mathrm{g} / \mathrm{kg} / \mathrm{min}$ received standard of care (SOC) or SOC + one single TPE. Here we report all clinical and biological endpoints of this study. Subgroup analysis of NE reduction and 28-day mortality was performed to investigate characteristics that could be associated with clinical response.

Results: Early hemodynamic stabilization was preserved in the TPE group for 24 hours and was accompanied by a reduction of lactate suggestive for shock reversal. A reduction of injurious mediators (such as PCT, vWF:Ag, Angpt-2, sTie-2) and a repletion of exhausted protective factors (such as AT-III, Protein C, ADAMTS-13) could be observed in the TPE but not in the SOC group. Significant NE reduction (> 50\% from baseline) upon TPE occurred more often in patients with 1) a pulmonary focus of infection, 2) profound respiratory failure $\left(\mathrm{pO}_{2} / \mathrm{FiO}_{2}<150 \mathrm{mmHg}\right)$, 3) critical hemodynamic instability ( $\mathrm{NE}>0.6$ $\mu \mathrm{g} / \mathrm{kg} / \mathrm{min}$ and lactate $>0.4 \mathrm{mmol} / \mathrm{l}$ ) as well as 4) substantial degree of organ failure (SOFA Score $>16$ ) at randomization. Patients with a pulmonary focus of infection had a 28 -day mortality of $15 \%$ in the TPE group while it was $42 \%$ in the SOC group.

Conclusions: Adjunctive TPE is associated with the removal of injurious mediators and repletion of consumed protective factors altogether leading to preserved hemodynamic stabilization in refractory septic shock. It is We identified potential response predictors (lung focus, PF ratio < 150, higher SOFA score etc.) that might guide future designing of large RCTs that will further evaluate TPE with regard to hard endpoints.

\section{Trial registration:}

Retrospectively registered $18^{\text {th }}$ January 2020 at clinicaltrials.gov (Identifier: NCT04231994), https://clinicaltrials.gov/ct2/show/NCT04231994?term=NCT04231994\&draw=2\&rank=1

\section{Background}

Sepsis is defined as life-threatening organ dysfunction caused by a dysregulated host response to infection and if hypotension is refractory to volume resuscitation with concurrent elevation of serum lactate it is termed septic shock (1). In the absence of a specific intervention other than anti-infectives, mortality remains exceedingly high (2). Although the overwhelming host response has been recognized as a key underlying pathophysiological concept in sepsis (3), still no specific treatment option aims for this causative target (4). Part of the failure to develop effective specific therapeutic strategies might be 
attributable to the complexity and non-linearity of sepsis pathophysiology making it unlikely for a single agent to successfully influence and rebalance the host response (5).

The theoretical concept of adjunctive therapeutic plasma exchange (TPE) in sepsis combines two major aspects in a singular intervention $(6,7)$ : Removal of injurious circulating molecules that directly contribute to the manifestation of the disease, including pro-inflammatory (Interleukin (IL)-6), permeability inducing- (e.g. Angiopoietin-2) and pro-coagulative (e.g. Willebrand Factor (vWF) Antigen) factors $(8,9)$. Equally important, the replacement of protective plasma proteins that compensate for the sepsisassociated loss of factors important for coagulation (e.g. activated protein $\mathrm{C}$, antithrombin), fibrinolysis (e.g. vWF cleaving proteases) and counteract inflammation and vascular leakage (e.g. Angiopoietin-1, immunoglobulins) (8-10). A meta-analysis identified 4 single-center randomized controlled trials (RCTs) that analyzed TPE in sepsis and found that TPE was associated with a reduced mortality in adult patients (11). However, the largest of those trials, which showed a trend towards improved survival, was underpowered and included a heterogeneous group of patients in terms of both disease severity and time of onset (12). Therefore, it remains unclear if TPE offers a survival benefit in patients with septic shock (13).

Recently, our group has demonstrated in an uncontrolled study that TPE, applied as an adjunctive treatment in patients with early ( $<24$ hours since shock onset) and severe (Norepinephrine (NE) dose > $0.4 \mu \mathrm{g} / \mathrm{kg} / \mathrm{min}$ ) septic shock, was associated with a rapid and significant reduction of catecholamine requirement (9). Employing the same inclusion criteria of early and severe septic shock, we then performed a bi-center RCT comparing adjunctive TPE to standard of care (SOC) which showed a median reduction in NE requirement by almost $50 \%$ within 6 hrs (14).

Here we report the full set clinical and biochemical endpoints of this study. Additionally, we performed a subgroup analysis of the primary endpoint NE reduction and the key secondary endpoint 28-day mortality in order to identify patients that have benefited most from adjunctive TPE. This additional analysis might enable more precise designing of future large RCT investigating TPE in septic shock.

\section{Methods}

\section{Study population}

This was a prospective bi-center open-label randomized controlled trial at the Medical School Hannover and the University Hospital of Bonn, Germany. We screened $n=1321$ patients submitted to the intensive care units (ICU) of both hospitals from June 2018 to July 2020 for the presence of septic shock per SEPSIS-3 definition and the below explained in-/ and exclusion criteria (1) (Figure 1). All patients were treated according to the 2012 Surviving Sepsis Campaign (SSC) guidelines (15). The ethical committee of Hannover Medical School (No. 2786-2015 and No. 8852_MPG_23b_2020) and University Hospital Bonn (No. 024/20) approved the protocol and written informed consent was obtained from participants or authorized representatives. The study was performed in accordance with the ethical standards laid 
down in the 1964 Declaration of Helsinki and its later amendments. The study was registered at clinicaltrials.gov (Identifier: NCT04231994).

\section{Inclusion \& Non-inclusion criteria}

Patients were included based on: (i) septic shock with ii) onset of vasopressor use $<24 \mathrm{hrs}$ prior to screening, and (iii) profound systemic hypotension requiring norepinephrine (NE) doses of $\geq 0.4$ $\mu \mathrm{g} / \mathrm{kg} / \mathrm{min}$ despite adequate intravenous fluid resuscitation ( $\geq 30 \mathrm{ml} / \mathrm{kg}$ bodyweight crystalloids). TPE had to be performed within $6 \mathrm{hrs}$ after the randomization process. As exclusion criteria, we defined pregnancy or breast feeding, age $<18$ years, end-stage chronic disease, and presence of a directive to withhold life-sustaining treatment.

\section{Therapeutic plasma exchange}

Vascular access was established by central venous insertion of an 11-French two-lumen hemodialysis catheter. Based on previous experiences only one TPE session was performed, since hemodynamic improvements were only achieved by the very first exchange (data not shown). TPE was performed against fresh frozen plasma (FFP), exchanging a fixed dose of 12 units of plasma $(3,262 \pm 350 \mathrm{ml}$ equal to $1 \pm 0.3$ times plasma volume) within $121 \pm 37$ min treatment time. Anticoagulation during TPE was achieved by regional citrate infusion. In patients with acute kidney injury (AKI), renal replacement therapy (RRT) was interrupted for the duration of TPE. Blood samples were drawn at randomization and 6 hours following randomization. Patients were closely followed for the next 28 days, and survival was recorded. NE dose was titrated every 10-15 min to maintain a mean arterial pressure (MAP) above $65 \mathrm{mmHg}$.

\section{Endpoints}

The primary endpoint was early hemodynamic improvement, indicated by absolute and relative NE reduction between randomization and 6 hrs following randomization.

Clinical secondary endpoints were: NE reduction between randomization and 24 hrs following randomization; reduction of the Vasoactive-Inotropic (VIS) Score (16) between randomization and 6 hrs as well as after $24 \mathrm{hrs;}$ Mean SOFA score over the first 9 days and 28-day mortality; Arterial lactate concentration, $\mathrm{pO}_{2} / \mathrm{FiO}_{2}$ ratio, total fluid balance, stroke volume variation (SVV), global end-diastolic volume index (GEDI), extravascular lung water index (ELWI), systemic vascular resistance index (SVRI), cardiac index $(\mathrm{Cl})$, all between randomization and $6 \mathrm{hrs}$ thereafter; free days of vasopressors, mechanical ventilation, renal replacement therapy (RRT) and ICU within the first 28 days.

Biochemical secondary endpoints were absolute and relative change of procalcitonine (PCT), antithrombin-III (AT-III), protein C, a disintegrin and metalloproteinase with a thrombospondin type 1 motif, member 13 (ADAMTS13) activity, von Willebrand Factor Antigen (vWF:Ag), Angiopoietin-2 (Angpt-2) as well as soluble angiopoietin receptor (sTie-2), all between randomization and $6 \mathrm{hrs}$ after randomization.

\section{Subgroup analysis}


Subgroup analyses were performed for the primary endpoint NE reduction and the key secondary endpoint 28-day mortality. For subgroup analysis of NE reduction, relative NE dose reduction of $>50 \%$ at $6 \mathrm{hrs}$ compared to baseline was analyzed. Both demographic and clinical parameters at randomization were analyzed between groups. For continuous parameters, values were dichotomized to $\leq$ and $>$ the median value of the complete study group at randomization before further analysis.

\section{Statistical analysis}

Data were presented as median (25-75\% IQR). Two-tailed $p$ values of less than 0.05 were considered to indicate statistical significance. Paired t-test or Wilcoxon-test (for not normal distributed variables) was utilized to compare longitudinal values. Survival data were analyzed by log-rank test and visualized by Kaplan-Meier curves. We compared the subgroups utilizing a $\chi 2$ test. Additional univariate regression analyses were performed employing both logistic regression (for endpoint NE reduction) as well as Cox regression (for endpoint 28-day mortality). We used GraphPad Prism 7 (La Jolla, CA) and SPSS Statistics (IBM) for data analysis and graph generation.

\section{Results}

\section{Cohort characterization}

Based on the strict criteria we included 40 out of 1321 initially screened patients admitted to two tertiary care hospital ICUs (Figure 1).

Demographic and clinical details are summarized in Table 1 demonstrating that both groups were comparable at randomization. Approximately, $80 \%$ of the patients were men with a median age around 55 years. The most common comorbidities were hypertension, obesity and diabetes. Pulmonary and abdominal infections were the most common cause of sepsis. In approximately $80 \%$ of patients, a causative pathogen, mostly gram+ and gram- bacteria was identified and all patients were treated with a combination of broad-spectrum antibiotics. The median [IQR] SOFA score at inclusion was 16 [14-19] highlighting the degree of multi-organ failure in the overall cohort. The median NE dose was $0.6 \mu \mathrm{g} / \mathrm{kg} / \mathrm{min}$, significantly higher than required for study inclusion ( $\geq 0.4 \mu \mathrm{g} / \mathrm{kg} / \mathrm{min})$. Ninety-three $\%$ of patients were mechanical ventilated due to respiratory failure and acute kidney injury (AKI) with need for renal replacement therapy (RRT) was present in $65 \%$ of the patients at inclusion. Despite continuous RRT and high dose vasopressor support, median lactate concentrations of 4 (2.6-6.1) mmol/I were detected underlining the severity of septic shock. Markedly increased values for C-reactive protein (CRP), procalcitonine (PCT) and white blood cell count (WBC) suggested highly pro-inflammatory milieu at randomization.

\section{Clinical endpoints}

The primary endpoint has been presented in a short report recently (14). In summary, the NE dose in the SOC group did not change within 6 hrs but the NE dose decreased significantly in the TPE group by $48 \%$ 
(summarized in Table 2).

Analyzing the long-term effects, we observed a preservation of this early effect even $24 \mathrm{hrs}$ after randomization. While NE dose was 0.36 [0.24-0.76] $\mathrm{gg} / \mathrm{kg} / \mathrm{min}$ in the SOC group, it was 0.18 [0.07-0.34] $\mu \mathrm{g} / \mathrm{kg} / \mathrm{min}$ in the TPE group ( $\mathrm{p}=0.01$, Table 2). This corresponded to an absolute NE dose reduction of $-0.12 \mu \mathrm{g} / \mathrm{kg} / \mathrm{min}$ in the SOC group compared to $-0.46 \mu \mathrm{g} / \mathrm{kg} / \mathrm{min}$ in the TPE group ( $p=0.001$, Table 2); the relative median NE dose reduction at 24 hrs compared to baseline was -24 [- 63 to +11 ) \% for control patients compared to $-72[-89$ to -58$] \%$ for TPE treated patients ( $<<0.0001$, Table 2).

To additionally investigate the effect of TPE on hemodynamics if further vasopressors (e.g. argipressin) as well as additional inotropes were required, we compared the VIS Score, which quantitatively summarizes cumulative doses of vasopressors and inotropes applied (16), between groups. The VIS score was unchanged in the SOC group at 6 hrs following randomization (VIS Score: 61 [46-85] vs 62 [41-146] points, $p=0.984$, Table 2 ). In contrast, in the TPE group the VIS Score was reduced by half ( 60 [55-87] vs 31 [21-43] points, $p<0.0001$, between-group difference at 6h: $p<0.0001$, Table 2). At 24 hrs following randomization a significant difference between groups remained $(p=0.028$, Table 2$)$.

Consistent with reduction of NE, lactate concentration showed a significant decline in the TPE group within 24 hrs after randomization ( $p=0.014)$, which was not found in the SOC group ( $p=0.628$, Table 2$)$. Total fluid balances increased in both groups during the first $24 \mathrm{hrs}$ and were not different between groups. However, stroke volume variation (SVV), a dynamic measure of preload, remained unchanged in the SOC group while it numerically decreased in the TPE group ( $p=0.069$ between group difference at 6 hrs, Table 2) indicating better intravascular filling. All other parameters measured by PiCCO (measured in a subgroup of 13 patients in the SOC and 11 in the TPE group) monitoring showed no differences between groups (Table 2).

Although, numerically lower in the TPE group, neither the mean SOFA Score over the first 9 days, nor the 28-day mortality were significantly different between groups (14). Patients in both groups had a comparable extent of total free days of ventilator, vasopressors, RRT and ICU during a 28-day period since randomization (Table 2).

\section{Biochemical endpoints}

PCT as a humoral marker of bacterial infection further increased in the SOC group, while it was reduced in the TPE group (PCT at $6 \mathrm{hrs}$ after randomization: 41.1 [12.2-103.9] vs 15 [4.9-39.7] $\mu \mathrm{g} / \mathrm{l}, \mathrm{p}=0.037$, Figure 2A).

Antithrombin (AT)-III increased in the TPE but not in the SOC group (AT-III at 6 hrs after randomization: 57 [47-69] vs 69 [63-78] \%, $p=0.026$, Figure $2 B$ ). The same observation was made for Protein $C$ (Protein $C$ at 6 hrs after randomization: 51 [27-67] vs 67 [60-82] \%, p=0.012, Figure 2C). ADAMTS-13 activity was unchanged in the SOC group, while it increased significantly in the TPE group C (ADAMTS-13 at 6 hrs after randomization: 41 [25-50] vs 47 [40-70] \%, p=0.008, Figure 2D). In contrast, vWF:Ag was 
profoundly reduced in the TPE group (vWF:Ag for TPE group at baseline vs. 6 hrs after randomization: 322 [202-367] vs. 98 [62-202] \%, p < 0.0001, Figure 2E), an effect not seen in the SOC group. Consequentially, the ratio of vWF:Ag to ADAMTS-13 activity was unchanged in the SOC group but significantly decreased in the TPE group (VWF:Ag/ADAMTS-13 at 6 hrs after randomization: 6.2 [2.7$10.5]$ vs $2.1[1.1-4], p=0.006$, Figure $2 F)$.

Angpt-2 concentration remained stable elevated in the SOC group but could be reduced in the TPE group (Angpt-2 at 6 hrs after randomization: $11.49[7.1-18.0]$ vs 6.1 [4.5-7.9] ng/ml, $p=0.009$, Figure $2 \mathrm{G}$ ). The same effect of TPE was observed for sTie-2 (sTie-2 at 6 hrs after randomization: 47.8 [42.4-63.6] vs 33.2 [29.9-41.6] ng/ml, $\mathrm{p}=0.005$, Figure $2 \mathrm{H}$ ).

\section{Subgroup analysis for the endpoint "early hemodynamic stabilization"}

Median reduction of NE in 6 hrs in the TPE group was $48 \%$ - yet the individual responses were quite heterogeneous. Therefore, we performed a subgroup analysis to further characterize TPE responders defined as a NE reduction of more than $50 \%$ from baseline (Figure 3 and Table 3 ) at 6 hrs after randomization.

A NE reduction $>50 \%$ from baseline was overall more likely in the TPE than in the SOC group (OR 5.7 [1.325.6], $p=0.024$ ). It was especially more likely to occur for patients in the TPE group if they were of male gender (OR 8.6 [1.4-51.4], $p=0.019$ ), and if sepsis origin was not hospital acquired (OR 19.2 [1.9-196.5], $p$ $=0.013)$. Patients benefited more from TPE when baseline vasopressor dose was higher $(p=0.009$ for NE dose, $p=0.009$ for VIS Score) and when the lactate concentration was $>4 \mathrm{mmol} / \mathrm{I}$ ( $40 \%$ in the TPE vs. $0 \%$ in the SOC group). Patients with a pulmonary focus of infection (OR 12.8 [1.3-130.5], $p=0.031$ ) and respiratory failure (OR 5.3 [1.2-24.2], $p=0.03$ ) benefited most from TPE in particular if gas exchange was severely compromised (i.e. $\mathrm{pO}_{2} / \mathrm{FiO}_{2}<150 \mathrm{mmHg}$ ) (OR 18.7 [1.6-222.9], $\mathrm{p}=0.021$ ). Furthermore, a higher baseline degree of systemic inflammation, indicated by PCT (OR 8.3 [1.1-67.1], $p=0.046$ ) above the median, was associated with a haemodynamic response to TPE. Patients with a SOFA Score $>16$ also had a more pronounced haemodynamic benefit from TPE (OR 8.3 [1.1-67.1], $p=0.046)$.

\section{Subgroup analysis for the endpoint "28-day mortality"}

Along the same lines, we further analyzed the secondary endpoint "28-day mortality" regarding subgroups that may have benefited from TPE (Figure 4 and Table 4). Overall, only numerically different results without statistical significance were found (HR 0.702 [0.277-1.783], $p=0.457$ ). Overall survival in the first 48 hours was $90 \%$ in the TPE and $70 \%$ in the SOC group $(p=0.095)$. However, trends could be observed when focus of infection, specific organ failures as well as baseline disease severity and degree of systemic inflammation were analyzed separately in a post hoc fashion. Patients with pulmonary focus of infection had a 28 -day mortality of only $15 \%$ in the TPE group while it was $42 \%$ in the SOC group (HR 0.297 [0.057-1.538], $p=0.148$, Kaplan Meier $p=0.095$ ). In contrast, mortality of patients with an abdominal focus of infection was high in both groups (67 vs 83\%, HR 1.575 [0.411-6.034], p = 0.507). Correspondingly, patients with lung specific organ failure showed a trend towards benefit from TPE (HR 
0.654 [0.258-1.661], $p=0.372$ ), while patients with liver failure did not (HR 1.501 [0.416-5.41], $p=0.535$ ). In general, the highest baseline disease severity of disease, e.g. patients with necessity of RRT, NE dose > $0.6 \mu \mathrm{g} / \mathrm{kg} / \mathrm{min}$, VIS Score $>61$, Lactate $>4 \mathrm{mmol} / \mathrm{l}, \mathrm{pO}_{2} / \mathrm{FiO}_{2}<150 \mathrm{mmHg}$ and SOFA Score $>16$, was associated with no benefit from TPE in terms of 28-day mortality. A PCT value $\leq 30 \mu \mathrm{g} / \mathrm{l}$ was associated with $67 \%$ survival in the TPE and $37 \%$ in the SOC group (HR 0.374 [0.099-1.408], $p=0.146$, Kaplan Meier $p=0.071)$.

\section{Discussion}

This prospective randomized bicentric trial shows that early TPE in patients with septic shock leads to hemodynamic stabilization. The primary endpoint showed a reduction of NE after 6 hrs following randomization of about $50 \%$ found in the TPE group. This early hemodynamic stabilization was also applicable for additional vasoactive and inotropic agents used (indicated by the VIS Score), was preserved 24 hours after randomization and was accompanied by a reduction of blood lactate indicating shock reversal in the TPE group. These results confirm earlier findings from non-randomized trials $(9,17)$. Although total fluid balance was not different between both groups, SVV was improved in the TPE cohort, which might indicate additional greater intravascular filling following TPE treatment. In accordance with this hypothesis, improved fluid balances have been observed repeatedly with additive TPE treatment before $(9,17)$.

In general, early hemodynamic stabilization by TPE was a robust finding across the subgroups studied. Significant (e.g. $>50 \%$ ) NE dose reduction occurred more often in the TPE group if patients presented with higher vasopressor doses ( $>0.6 \mu \mathrm{g} / \mathrm{kg} / \mathrm{min}$ ) and lactate concentrations ( $>4 \mathrm{mmol} / \mathrm{l})$ at time of randomization. Furthermore, profound multi-organ failure (i.e. SOFA Score $>16$ ) was associated with a haemodynamic response to TPE, a finding in line with previous un-controlled observations (17). Of note, a pulmonary focus of infection and corresponding lung failure, were predictors of early hemodynamic stabilization by adjunctive TPE.

In contrast to other modalities of adjunctive extracorporeal sepsis treatment (7), TPE has the potential to not only remove excessive potentially injurious mediators (e.g. cytokines) but also to replace depleted protective factors that can be found in physiological concentrations within the healthy donor plasma used for the exchange (6). Consistently, we observed with TPE a reduction of injurious mediators such as PCT, vWF:Ag, Angpt-2, sTie-2 and a repletion of decreased protective factors such as AT-III, Protein C, ADAMTS-13, which were not seen in the control group.

Increased PCT concentrations have been closely associated with reduced survival in both preclinical sepsis models $(18,19)$ as well as clinical observations $(20)$. Some data indicate that PCT is not only a biomarker but might also be a disease mediator making it interesting as a potential therapeutic target (18). Therefore, the observation that a circulating marker/meditator like PCT could be lowered after TPE to half of the control group level is of potential importance. 
Supplementation of septic patients with AT-III has been investigated for a long time and did not show a mortality benefit in early trials involving heterogeneous patient populations (21). It might however reduce mortality in selected highly unstable septic patients, including those with disseminated intravascular coagulation (DIC) (22-24). Median ISTH-DIC score in our study was 4 (3-5) with elevated D-Dimers of 7.9 (3-18.2) $\mathrm{mg} / \mathrm{l}$, indicating non-overt DIC in the overall cohort with overt DIC in some patients. Depletion of the endogenous anticoagulation factor "protein C" by increased consumption, degradation, and/or decreased synthesis, is a well-described characteristic of sepsis and has been shown to predict mortality in sepsis (25). Interestingly, substitution of its activated form termed Drotrecogin alfa improved 28-day survival in the initial randomized controlled trial (26), but failed to reproduce these findings in a later confirmatory study of patients with septic shock (27). Heterogeneity of distinct biological and clinical sepsis phenotypes that might respond different to specific therapeutic measures such as protein $\mathrm{C}$ supplementation might in part explain these conflicting results (28). Especially severe deficiency of protein C (e.g. in purpura fulminans) is associated with inferior outcomes in sepsis (25) and treatment options, including protein $\mathrm{C}$ supplementation, are continued to be evaluated in these selected patients (29, 30). Median protein $C$ activity of our cohort at randomization was 54.5 (39.8-70) \%, indicating protein $C$ deficiency to a certain extend in all patients. Of note, TPE did increase AT-III activity.

Severe ADAMTS13 deficiency (the VWF cleaving protease) causes accumulation of ultra-large VWF multimers (ULVWF) that can lead to the clinical picture of thrombotic microangiopathy as seen in its most severe form in thrombotic thrombocytopenic purpura (TTP) (31). Interestingly, a deficiency of ADAMTS13 is also detectable in sepsis (32-34). At the same time, large amounts of vWF:Ag are secreted by the activated septic endothelium leading to both increased platelet aggregation and formation of highly pro-thrombotic ULVWF multimers [16]. Consequentially, an increased vWF:Ag/ADAMTS13 ratio has been repeatedly associated with severity of shock and organ failure as well as increased mortality in sepsis $(32,35-38)$. Median ADAMTS13 activity was lowered to $43 \%$ with a relatively wide IQR of 25 to $55 \%$. ADAMTS13 activity below $45 \%$ has already been associated with increased mortality in sepsis (37), activity below $30 \%$ with significantly higher systemic inflammation (i.e. IL-6 concentrations) (36) and greater incidence of overt DIC (33). While we did not measure ULVWF multimers, vWF:Ag concentration was more than three times as high as normal at baseline but normalized in patients following a singular TPE treatment.

Angpt-2, a pre-stored protein secreted by stimulated endothelium and an antagonist of the vascular barrier protective receptor Tie2, contributes to the pathophysiology of septic multiple organ dysfunction (39-41). Increased circulating Angpt-2 concentrations are associated with both organ failure and mortality in septic patients (42) and initial Angpt-2 concentrations below $9.2 \mathrm{ng} / \mathrm{ml}$ have been associated with favorable survival. Here we show a significant reduction of circulating Angpt-2 following TPE to around 6 $\mathrm{ng} / \mathrm{ml}$, while it remains elevated in the control group. Finally, cleaved circulating receptor binding domain sTie2 has been demonstrated to locally inhibit endothelium protective Angpt-1 signaling by trapping protective Angpt- 1 (43). Of note, sTie2 circulating concentration was reduced by $30 \%$ following a singular TPE session. 
This exploratory study was not powered to demonstrate a difference in organ dysfunction or mortality. Thus, although numerical trends were observed for the TPE group towards lower median SOFA Scores and 28-day mortalities, no statistically significant differences could be observed. Recent retrospective analyses have suggested lower degrees of organ dysfunction as well as mortality in septic shock patients following treatment with adjunctive TPE $(17,44)$. In a recent propensity-score matched retrospective analysis, patients with pneumonia as the primary site of infection demonstrated the greatest improvement in 28-day mortality by additive TPE (17). Consistent with this observation we found that patients with a lung focus of infection had a better response to TPE with 28 -day mortality of $15 \%$ compared to $42 \%$ in the control group. In terms of response prediction it is of interest that the sickest patients in this study (e.g. NE dose $>0.6 \mu \mathrm{g} / \mathrm{kg} / \mathrm{min}$, Lactate $>4 \mathrm{mmol} / \mathrm{l}$, SOFA Score $>16$ at baseline) did still benefit from TPE treatment with regard to early hemodynamic stabilization but their outcome was still worse compared to less critically ill patients. While this observation might not be entirely unexpected, it helps to plan stratification of a larger future RCT investigation TPE in septic shock.

TPE has been investigated as an adjunctive treatment modality for sepsis earlier $(9,12,17,44-47)$ with overall inconclusive results (11) preventing advice towards a routine use (48). The informative value of these previous studies was limited by both a heterogeneity of the incorporated inclusion criteria (e.g. adult and pediatric patients, patients with and without shock, different durations of sepsis shock onset before inclusion) as well as the non-randomized nature of most studies. A major strength of this current trial therefore is a homogenization of the patient cohort investigated by only including patients with severe (NE dose $>0.4 \mu \mathrm{g} / \mathrm{kg} / \mathrm{min}$ ) and early ( $<24 \mathrm{hrs}$ since onset) septic shock. By assessing, in addition to the clinical data presented, a collection of (non-routinely measured) biochemical parameters, we suggest a possible pathophysiological explanation for the observed improved hemodynamic stabilization found following TPE. The ability to replace multiple depleted protective factors involved in sepsis pathophysiology clearly sets TPE apart from other extracorporeal treatment modalities employed in sepsis care (6). In contrast, unselective removal of both harmful and protective factors (49) might contribute to increased mortality reported recently for additive cytokine adsorption in severe ARDS and septic shock $(50,51)$.

More recently, distinct biological and clinical sepsis phenotypes have been identified that might respond different to specific therapeutic measures (28) and one of the major challenges in future precision medicine orientated sepsis therapy will lie in the correct identification of subgroups that might benefit most from a certain additive therapy modality. Here we could demonstrate in subgroup analyses that TPE was especially effective, in terms of early hemodynamic stabilization, in patients with a pulmonary focus of infection, lung failure, critical hemodynamic instability and multi-organ failure. These characteristics have been identified previously as a so-called $\mathrm{y}$-sepsis phenotype, which has been predicted to respond well to specific additive measures of sepsis therapy (28).

This study has important limitations, mainly its small sample size, preventing to draw conclusions about hard endpoints such as organ-dysfunction or mortality. In addition, the intervention was administered as a singular regimen and at a fixed dose, which precludes us from providing data on effects at different 
dosages or time frames. This explorative study was not designed to assess survival but to assess in a randomized design preliminary efficacy as indicated by early hemodynamic randomization and to identify patients that may have benefited most from adjunctive TPE.

\section{Conclusions}

Our explorative randomized study demonstrated rapid hemodynamic stabilization following adjunctive TPE in a subgroup of early septic shock patients. Observations with regard to response prediction may guide future designing of a randomized, controlled multi-center study to further investigate this treatment modality.

\section{Abbreviations}

ADAMTS13 = A disintegrin and metalloprotease with thrombospondin-1-like domains 13

AT-III = Antithrombin-III

$\mathrm{BMI}=$ Body mass index

$C A D=$ Coronary artery disease

CKD $=$ Chronic kidney disease

$\mathrm{CHF}=$ Congestive heart failure

$\mathrm{Cl}=$ Cardiac index

COPD = Chronic obstructive pulmonary disease

$\mathrm{CRP}=\mathrm{C}$-reactive protein

$\mathrm{ECMO}=$ Extracorporeal membrane oxygenation $(\mathrm{vv}=$ venovenous, va $=$ venoarterial $)$

$E L W I=$ Extravascular lung water index

FFP $=$ Fresh frozen plasma

GEDI = Global enddiastolic index

HSCT $=$ Hematopoietic stem cell transplant

$\mathrm{HR}=$ Hazard Ratio

$\mathrm{ICU}=$ Intensive care unit

$\mathrm{IL}=$ Interleukin 
MAP = Mean arterial pressure

$\mathrm{NE}=$ Norepinephrine

$\mathrm{OR}=$ Odds ratio

$\mathrm{PCT}=$ Procalcitonine

RCT = Randomized controlled trial

RRT $=$ Renal replacement therapy

SOC $=$ Standard of Care

SOFA $=$ Sequential Organ Failure Assessment

SOT $=$ Solid organ transplant

sTie2 $=$ a Soluble receptor of tyrosine kinase with immunoglobulin-like and EGF-like domains 2

$S V V=$ Stroke volume variation

SVRI = Systemic vascular resistance index

TPE $=$ Therapeutic plasma exchange

ULVWF = Ultra large $v W F$ multimers

VIS = Vasoactive-Inotropic Score

vWF:Ag = Von-Willebrandt Factor Antigen

WBC $=$ White blood cell count

\section{Declarations}

\section{Ethics approval and consent to participate}

The ethical committee of Hannover Medical School (No. 2786-2015 and No. 8852_MPG_23b_2020) and University Hospital Bonn (No. 024/20) approved the protocol and written informed consent was obtained from participants or authorized representatives. The study was performed in accordance with the ethical standards laid down in the 1964 Declaration of Helsinki and its later amendments. The study was registered at clinicaltrials.gov (Identifier: NCT04231994).

Consent of publication - Not applicable 
The datasets used and analyzed are during the current study are available from the corresponding author on reasonable request.

Competing interests - The authors declare that they have no competing interest.

\section{Funding}

Laboratory experiments were supported by a grant from the German Research Foundation to SD (DA1209/4-3).

\section{Authors contributions}

KS and PW collected clinical data from the PDMS. KS and SD calculated statistics and generated the figures for publication. BMWS was the leading nephrology consultant coordinating and performing the plasma exchange on our unit. UB performed experiments involving ADAMTS13 and vWF:Ag. BS, JJS, FL, $A S, M B, O W, C P, M M H, C B$ and SD recruited patients and generated thermodilution cardiac output data. $\mathrm{MMH}, \mathrm{TW}, \mathrm{HH}, \mathrm{HW}, \mathrm{CP}, \mathrm{PW}, \mathrm{BS}, \mathrm{JJS}, \mathrm{CB}, \mathrm{KS}$ and SD interpreted data and wrote the manuscript. KS and SD had the original idea for this trial and wrote the proposals. All authors read an approved the final manuscript.

\section{Acknowledgements}

Not applicable.

\section{References}

1. Singer M, Deutschman CS, Seymour CW, Shankar-Hari M, Annane D, Bauer M, et al. The Third International Consensus Definitions for Sepsis and Septic Shock (Sepsis-3). Jama. 2016;315(8):801-10.

2. Fleischmann C, Thomas-Rueddel DO, Hartmann M, Hartog CS, Welte T, Heublein S, et al. Hospital Incidence and Mortality Rates of Sepsis. Deutsches Arzteblatt international. 2016;113(10):159-66.

3. Angus DC, van der Poll T. Severe sepsis and septic shock. The New England journal of medicine. 2013;369(9):840-51.

4. Rhodes A, Evans LE, Alhazzani W, Levy MM, Antonelli M, Ferrer R, et al. Surviving Sepsis Campaign: International Guidelines for Management of Sepsis and Septic Shock: 2016. Intensive care medicine. 2017;43(3):304-77.

5. Steinhagen F, Schmidt SV, Schewe JC, Peukert K, Klinman DM, Bode C. Immunotherapy in sepsis brake or accelerate? Pharmacology \& therapeutics. 2020;208:107476.

6. David S, Stahl K. To remove and replace-a role for plasma exchange in counterbalancing the host response in sepsis. Critical care (London, England). 2019;23(1):14. 
7. Stahl K, Bode C, David S. [Extracorporeal Strategies in Sepsis Treatment: Role of Therapeutic Plasma Exchange]. Anasthesiologie, Intensivmedizin, Notfallmedizin, Schmerztherapie : AINS. 2021;56(2):101-10.

8. Stahl K, Schmidt JJ, Seeliger B, Schmidt BMW, Welte T, Haller H, et al. Effect of therapeutic plasma exchange on endothelial activation and coagulation-related parameters in septic shock. Critical care (London, England). 2020;24(1):71.

9. Knaup H, Stahl K, Schmidt BMW, Idowu TO, Busch M, Wiesner O, et al. Early therapeutic plasma exchange in septic shock: a prospective open-label nonrandomized pilot study focusing on safety, hemodynamics, vascular barrier function, and biologic markers. Critical care (London, England). 2018;22(1):285.

10. Stahl K, Bikker R, Seeliger B, Schmidt JJ, Schenk H, Schmidt BMW, et al. Effect of Therapeutic Plasma Exchange on Immunoglobulin Deficiency in Early and Severe Septic Shock. Journal of intensive care medicine. 2020:885066620965169.

11. Rimmer E, Houston BL, Kumar A, Abou-Setta AM, Friesen C, Marshall JC, et al. The efficacy and safety of plasma exchange in patients with sepsis and septic shock: a systematic review and meta-analysis. Critical care (London, England). 2014;18(6):699.

12. Busund R, Koukline V, Utrobin U, Nedashkovsky E. Plasmapheresis in severe sepsis and septic shock: a prospective, randomised, controlled trial. Intensive care medicine. 2002;28(10):1434-9.

13. Schwartz J, Padmanabhan A, Aqui N, Balogun RA, Connelly-Smith L, Delaney M, et al. Guidelines on the Use of Therapeutic Apheresis in Clinical Practice-Evidence-Based Approach from the Writing Committee of the American Society for Apheresis: The Seventh Special Issue. Journal of clinical apheresis. 2016;31(3):149-62.

14. David S, Bode C, Putensen C, Welte T, Stahl K. Adjuvant therapeutic plasma exchange in septic shock. Intensive care medicine. 2021;47(3):352-4.

15. Dellinger RP, Levy MM, Rhodes A, Annane D, Gerlach H, Opal SM, et al. Surviving Sepsis Campaign: international guidelines for management of severe sepsis and septic shock, 2012. Intensive care medicine. 2013;39(2):165-228.

16. McIntosh AM, Tong S, Deakyne SJ, Davidson JA, Scott HF. Validation of the Vasoactive-Inotropic Score in Pediatric Sepsis. Pediatric critical care medicine : a journal of the Society of Critical Care Medicine and the World Federation of Pediatric Intensive and Critical Care Societies. 2017;18(8):750-7.

17. Keith PD, Wells AH, Hodges J, Fast SH, Adams A, Scott LK. The therapeutic efficacy of adjunct therapeutic plasma exchange for septic shock with multiple organ failure: a single-center experience. Critical care (London, England). 2020;24(1):518. 
18. Nylen ES, Whang KT, Snider RH, Jr., Steinwald PM, White JC, Becker KL. Mortality is increased by procalcitonin and decreased by an antiserum reactive to procalcitonin in experimental sepsis. Critical care medicine. 1998;26(6):1001-6.

19. Becker KL, Snider R, Nylen ES. Procalcitonin in sepsis and systemic inflammation: a harmful biomarker and a therapeutic target. British journal of pharmacology. 2010;159(2):253-64.

20. Adamik B, Smiechowicz J, Jakubczyk D, Kübler A. Elevated Serum PCT in Septic Shock With Endotoxemia Is Associated With a Higher Mortality Rate. Medicine. 2015;94(27):e1085.

21. Warren BL, Eid A, Singer P, Pillay SS, Carl P, Novak I, et al. Caring for the critically ill patient. High-dose antithrombin III in severe sepsis: a randomized controlled trial. Jama. 2001;286(15):1869-78.

22. Hayakawa M, Kudo D, Saito S, Uchino S, Yamakawa K, lizuka Y, et al. Antithrombin Supplementation and Mortality in Sepsis-Induced Disseminated Intravascular Coagulation: A Multicenter Retrospective Observational Study. Shock (Augusta, Ga). 2016;46(6):623-31.

23. Tagami T, Matsui H, Horiguchi H, Fushimi K, Yasunaga H. Antithrombin and mortality in severe pneumonia patients with sepsis-associated disseminated intravascular coagulation: an observational nationwide study. Journal of thrombosis and haemostasis : JTH. 2014;12(9):1470-9.

24. Wiedermann CJ, Hoffmann JN, Juers M, Ostermann H, Kienast J, Briegel J, et al. High-dose antithrombin III in the treatment of severe sepsis in patients with a high risk of death: efficacy and safety. Critical care medicine. 2006;34(2):285-92.

25. Shorr AF, Bernard GR, Dhainaut JF, Russell JR, Macias WL, Nelson DR, et al. Protein C concentrations in severe sepsis: an early directional change in plasma levels predicts outcome. Critical care (London, England). 2006;10(3):R92.

26. Bernard GR, Vincent JL, Laterre PF, LaRosa SP, Dhainaut JF, Lopez-Rodriguez A, et al. Efficacy and safety of recombinant human activated protein $\mathrm{C}$ for severe sepsis. The New England journal of medicine. 2001;344(10):699-709.

27. Ranieri VM, Thompson BT, Barie PS, Dhainaut JF, Douglas IS, Finfer S, et al. Drotrecogin alfa (activated) in adults with septic shock. The New England journal of medicine. 2012;366(22):2055-64.

28. Seymour CW, Kennedy JN, Wang S, Chang CH, Elliott CF, Xu Z, et al. Derivation, Validation, and Potential Treatment Implications of Novel Clinical Phenotypes for Sepsis. Jama. 2019;321(20):2003-17.

29. Brunkhorst FM, Patchev V. [Sepsis-associated Purpura Fulminans International Registry--Europe (SAPFIRE)]. Medizinische Klinik, Intensivmedizin und Notfallmedizin. 2014;109(8):591-5.

30. Knoebl P, Schellongowski P, Staudinger T, Sperr WR, Scheibenpflug C. Treatment Of InfectionAssociated Purpura Fulminans With Protein C Zymogen Is Associated With a High Survival Rate. Blood. 
2013;122(21):3606-.

31. Levy GG, Nichols WC, Lian EC, Foroud T, McClintick JN, McGee BM, et al. Mutations in a member of the ADAMTS gene family cause thrombotic thrombocytopenic purpura. Nature. 2001;413(6855):488-94.

32. Aibar J, Castro P, Espinosa G, Fernández S, Hernández C, Rinaudo M, et al. ADAMTS-13 in Critically III Patients With Septic Syndromes and Noninfectious Systemic Inflammatory Response Syndrome. Shock (Augusta, Ga). 2015;43(6):556-62.

33. Bockmeyer CL, Claus RA, Budde U, Kentouche K, Schneppenheim R, Lösche W, et al. Inflammationassociated ADAMTS13 deficiency promotes formation of ultra-large von Willebrand factor. Haematologica. 2008;93(1):137-40.

34. Kremer Hovinga JA, Zeerleder S, Kessler P, Romani de Wit T, van Mourik JA, Hack CE, et al. ADAMTS13 , von Willebrand factor and related parameters in severe sepsis and septic shock. Journal of thrombosis and haemostasis : JTH. 2007;5(11):2284-90.

35. Ono T, Mimuro J, Madoiwa S, Soejima K, Kashiwakura Y, Ishiwata A, et al. Severe secondary deficiency of von Willebrand factor-cleaving protease (ADAMTS13) in patients with sepsis-induced disseminated intravascular coagulation: its correlation with development of renal failure. Blood. 2006;107(2):528-34.

36. Peigne V, Azoulay E, Coquet I, Mariotte E, Darmon M, Legendre P, et al. The prognostic value of ADAMTS13 (a disintegrin and metalloprotease with thrombospondin type 1 repeats, member 13) deficiency in septic shock patients involves interleukin- 6 and is not dependent on disseminated intravascular coagulation. Critical care (London, England). 2013;17(6):R273.

37. Lin JJ, Chan OW, Hsiao HJ, Wang Y, Hsia SH, Chiu CH. Decreased ADAMTS 13 Activity is Associated With Disease Severity and Outcome in Pediatric Severe Sepsis. Medicine. 2016;95(16):e3374.

38. Claus RA, Bockmeyer CL, Budde U, Kentouche K, Sossdorf M, Hilberg T, et al. Variations in the ratio between von Willebrand factor and its cleaving protease during systemic inflammation and association with severity and prognosis of organ failure. Thrombosis and haemostasis. 2009;101(2):239-47.

39. Stiehl T, Thamm K, Kaufmann J, Schaeper U, Kirsch T, Haller H, et al. Lung-targeted RNA interference against angiopoietin-2 ameliorates multiple organ dysfunction and death in sepsis. Critical care medicine. 2014;42(10):e654-62.

40. David S, Mukherjee A, Ghosh CC, Yano M, Khankin EV, Wenger JB, et al. Angiopoietin-2 may contribute to multiple organ dysfunction and death in sepsis*. Critical care medicine. 2012;40(11):3034-41.

41. Kumpers P, Gueler F, David S, Slyke PV, Dumont DJ, Park JK, et al. The synthetic tie2 agonist peptide vasculotide protects against vascular leakage and reduces mortality in murine abdominal sepsis. Critical care (London, England). 2011;15(5):R261.

Page $17 / 30$ 
42. Kümpers $P$, Hafer $C$, David S, Hecker H, Lukasz A, Fliser D, et al. Angiopoietin-2 in patients requiring renal replacement therapy in the ICU: relation to acute kidney injury, multiple organ dysfunction syndrome and outcome. Intensive care medicine. 2010;36(3):462-70.

43. Alawo DOA, Tahir TA, Fischer M, Bates DG, Amirova SR, Brindle NPJ. Regulation of Angiopoietin Signalling by Soluble Tie2 Ectodomain and Engineered Ligand Trap. Scientific reports. 2017;7(1):3658.

44. Aydin K, Korkmaz S, Erkurt MA, Sarici A, Ekinci O, Baysal NA, et al. Apheresis in patients with sepsis: A multicenter retrospective study. Transfusion and apheresis science : official journal of the World Apheresis Association : official journal of the European Society for Haemapheresis. 2021:103239.

45. Reeves JH, Butt WW, Shann F, Layton JE, Stewart A, Waring PM, et al. Continuous plasmafiltration in sepsis syndrome. Plasmafiltration in Sepsis Study Group. Critical care medicine. 1999;27(10):2096-104.

46. Nguyen TC, Han YY, Kiss JE, Hall MW, Hassett AC, Jaffe R, et al. Intensive plasma exchange increases a disintegrin and metalloprotease with thrombospondin motifs- 13 activity and reverses organ dysfunction in children with thrombocytopenia-associated multiple organ failure. Critical care medicine. 2008;36(10):2878-87.

47. Long EJ, Taylor A, Delzoppo C, Shann F, Pearson G, Buckley D, et al. A randomised controlled trial of plasma filtration in severe paediatric sepsis. Critical care and resuscitation : journal of the Australasian Academy of Critical Care Medicine. 2013;15(3):198-204.

48. Padmanabhan A, Connelly-Smith L, Aqui N, Balogun RA, Klingel R, Meyer E, et al. Guidelines on the Use of Therapeutic Apheresis in Clinical Practice - Evidence-Based Approach from the Writing Committee of the American Society for Apheresis: The Eighth Special Issue. Journal of clinical apheresis. 2019;34(3):171-354.

49. Seeliger B, Stahl K, David S. [Extracorporeal techniques for blood purification in sepsis: an update]. Der Internist. 2020;61(10):1010-6.

50. Supady A, Weber E, Rieder M, Lother A, Niklaus T, Zahn T, et al. Cytokine adsorption in patients with severe COVID-19 pneumonia requiring extracorporeal membrane oxygenation (CYCOV): a single centre, open-label, randomised, controlled trial. The Lancet Respiratory medicine. 2021;9(7):755-62.

51. Wendel Garcia PD, Hilty MP, Held U, Kleinert EM, Maggiorini M. Cytokine adsorption in severe, refractory septic shock. Intensive care medicine. 2021:1-3.

\section{Tables}


Table 1

Demographic and clinical parameters at study inclusion

\begin{tabular}{|c|c|c|c|c|}
\hline Category & All & soc & TPE & $\mathbf{p}$ \\
\hline & $\mathrm{n}=40$ & $\mathrm{n}=20$ & $\mathrm{n}=20$ & \\
\hline Age - years & $56(47-63)$ & $57(46-65)$ & $55(48-60)$ & 0.663 \\
\hline Sex - no (\%) & & & & 0.429 \\
\hline male & $32(80)$ & $17(85)$ & $15(75)$ & \\
\hline female & $8(20)$ & $3(15)$ & $5(25)$ & \\
\hline $\mathrm{BMI}-\mathrm{kg} / \mathrm{m}^{2}$ & $25.4(22.6-32.3)$ & $25.5(24.1-35.4)$ & $25.1(20.2-31.1)$ & 0.114 \\
\hline \multicolumn{5}{|l|}{ Comorbidities - no (\%) } \\
\hline Obesity & $12(30)$ & $6(30)$ & $6(30)$ & 1 \\
\hline Hypertension & $17(42.5)$ & $9(45)$ & $8(40)$ & 0.749 \\
\hline Diabetes & $6(15)$ & $5(25)$ & $1(5)$ & 0.077 \\
\hline COPD & $4(10)$ & $3(15)$ & $1(5)$ & 0.292 \\
\hline CHF & $7(17.5)$ & $4(20)$ & $3(15)$ & 0.677 \\
\hline CAD & $4(10)$ & $2(10)$ & $2(10)$ & 1 \\
\hline CKD & $7(17.5)$ & $4(20)$ & $3(15)$ & 0.677 \\
\hline Immunosuppression & $8(20)$ & $3(15)$ & $5(25)$ & 0.429 \\
\hline SOT or HSCT & $5(12.5)$ & $3(15)$ & $2(10)$ & 0.633 \\
\hline \multicolumn{5}{|l|}{ Sepsis onset - no (\%) } \\
\hline ambulatory & $26(65)$ & $13(65)$ & $13(65)$ & 1 \\
\hline hospital & $14(35)$ & $7(35)$ & $7(35)$ & 1 \\
\hline \multicolumn{5}{|c|}{ Side of infection - no (\%) } \\
\hline pulmo & $25(62.5)$ & $12(60)$ & $13(65)$ & 0.744 \\
\hline abdomen & $12(30)$ & $6(30)$ & $6(30)$ & 1 \\
\hline soft tissue & $2(5)$ & $2(10)$ & $0(0)$ & 0.147 \\
\hline endocarditis & $1(2.5)$ & $0(0)$ & $1(5)$ & 0.311 \\
\hline \multicolumn{5}{|c|}{ identified pathogen - no (\%) } \\
\hline gram+ & $12(30)$ & $6(30)$ & $6(30)$ & 1 \\
\hline
\end{tabular}




\begin{tabular}{|c|c|c|c|c|}
\hline Category & All & soc & TPE & $\mathbf{p}$ \\
\hline gram- & $12(30)$ & $5(25)$ & $7(35)$ & 0.49 \\
\hline fungi & $2(5)$ & $1(5)$ & $1(5)$ & 1 \\
\hline viral & $3(7.5)$ & $2(10)$ & $1(5)$ & 0.548 \\
\hline mixed & $2(5)$ & $2(10)$ & $0(0)$ & 0.147 \\
\hline non identified & $9(22.5)$ & $4(20)$ & $5(25)$ & 0.705 \\
\hline SOFA score (points) & $16.5(14-19)$ & $18(14-20)$ & $16(13-18)$ & 0.125 \\
\hline $\begin{array}{l}\text { Norepinephrine dose } \\
(\mu \mathrm{g} / \mathrm{kg} / \mathrm{min})\end{array}$ & $\begin{array}{l}0.591(0.468- \\
0.84)\end{array}$ & $\begin{array}{l}0.582(0.458- \\
0.84)\end{array}$ & $\begin{array}{l}0.598(0.549- \\
0.867)\end{array}$ & 0.724 \\
\hline VIS Score (points) & $61(48-85)$ & $61(46-85)$ & $60(55-87)$ & 0.98 \\
\hline Mechanical ventilation - no (\%) & $37(92.5)$ & $18(90)$ & $19(95)$ & 0.548 \\
\hline $\begin{array}{l}\text { Oxygenierungsindex } \\
\left(\mathrm{PaO}_{2} / \mathrm{FiO}_{2}\right)\end{array}$ & $145(97-243)$ & $156(81-221)$ & $132(98-278)$ & 0.624 \\
\hline \multicolumn{5}{|l|}{ ECMO - no (\%) } \\
\hline vv-ECMO & $9(22.5)$ & $4(20)$ & $5(25)$ & 0.705 \\
\hline va-ECMO & $2(5)$ & $2(10)$ & $0(0)$ & 0.147 \\
\hline $\begin{array}{l}\text { Renal replacement therapy - no } \\
(\%)\end{array}$ & $26(65)$ & $14(70)$ & $12(60)$ & 0.507 \\
\hline Lactate - mmol// & $4(2.6-6.1)$ & $4.4(2.6-6.9)$ & $4(2.6-5.9)$ & 0.513 \\
\hline \multicolumn{5}{|l|}{ Organ failure - no (\%) } \\
\hline respiratory & $39(97.5)$ & $19(95)$ & $20(100)$ & 0.311 \\
\hline coagulation & $19(47.5)$ & $10(50)$ & $9(45)$ & 0.752 \\
\hline liver & $16(40)$ & $11(55)$ & $5(25)$ & 0.053 \\
\hline cardiovascular & $40(100)$ & $20(100)$ & $20(100)$ & 1 \\
\hline neurological & $39(97.5)$ & $20(100)$ & $19(95)$ & 0.311 \\
\hline renal & $32(80)$ & $16(80)$ & $16(80)$ & 1 \\
\hline CRP (mg/l) & $297(168-350)$ & 279 (115-410) & $297(213-350)$ & 0.698 \\
\hline PCT $(\mu \mathrm{g} / \mathrm{l})$ & $30(7-82)$ & $36(13-101)$ & $20(6-59)$ & 0.159 \\
\hline $\operatorname{WBC}\left(10^{3} / \mu \mathrm{l}\right)$ & $17(8-20)$ & $12(5-18)$ & $18(10-23)$ & 0.244 \\
\hline
\end{tabular}


TABLE 2 - Primary and secondary clinical endpoints. Shown are primary and secondary clinical outcomes for patients receiving Standard of Care Treatment (SOC) as well as patients receiving additive Therapeutic Plasma Exchange (TPE). Endpoints are compared both longitudinally at 0, 6 and 24 hrs following randomization as well as between SOC and TPE groups.
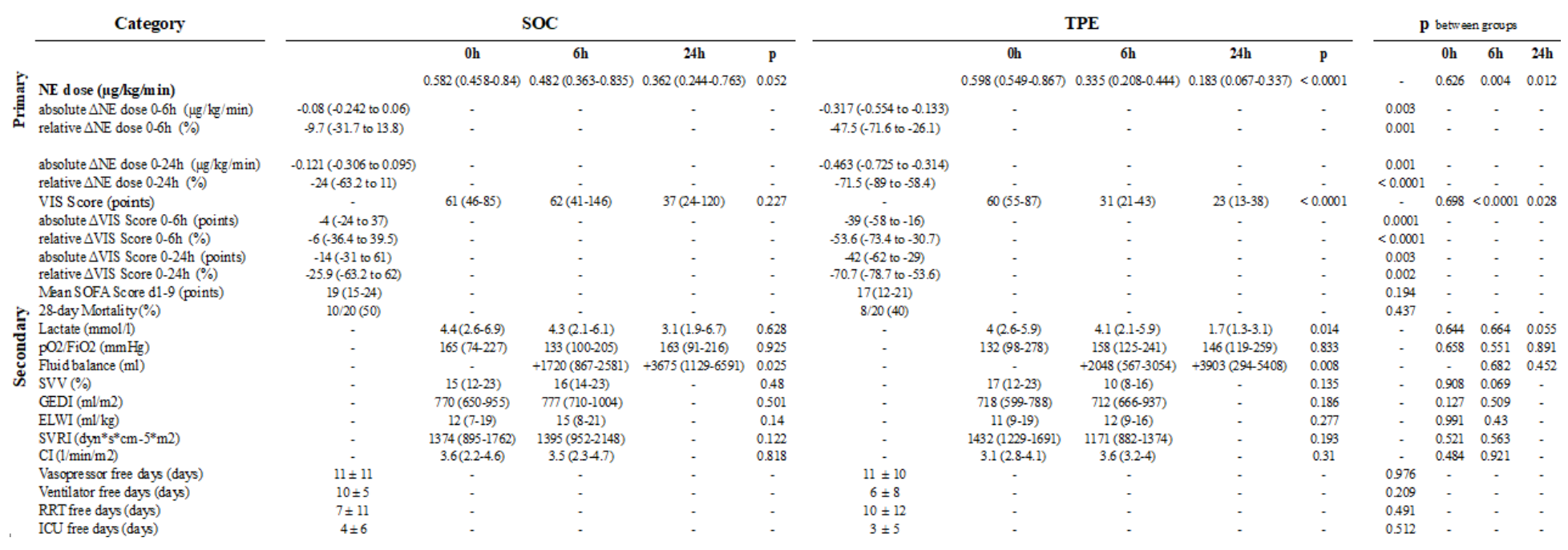

$\mathrm{Cl}=$ Cardiac index, $\mathrm{ELWI}=$ Extravascular lung water index, GEDI = Global enddiastolic index, ICU = Intensive care unit, MAP = Mean arterial pressure, NE = Norepinephrine, RRT = Renal replacement therapy, SOFA = Sequential Organ Failure Assessment, SVV = Stroke volume variation, SVRI = Systemic vascular resistance index, VIS = Vasoactive-Inotropic Score

\section{TABLE 3 - Subgroup analysis for primary endpoint Norepinephrine dose reduction $>\mathbf{5 0} \%$ from}

baseline. Subgroup analysis for relative NE dose reduction of $>50 \%$ at $6 \mathrm{hrs}$ compared to baseline. Both demographic and clinical parameters at randomization were analyzed between groups. For continuous parameters, values were dichotomized to $\leq$ and $>$ the median value of the complete study group at randomization before further analysis. Shown are both descriptive data analyzed by Chi-square tests as well as results of a logistic regression. 
Characteristic (at randomisation)

No. of

events/total

no. (\%)
Logistic

Regression

\begin{tabular}{|c|c|c|c|c|c|c|c|}
\hline - & - & soc & TPE & $\mathbf{p}$ & OR & $\begin{array}{l}95 \%- \\
\mathrm{Cl}\end{array}$ & $\mathbf{p}$ \\
\hline All & - & $\begin{array}{l}3 / 20 \\
(15)\end{array}$ & $\begin{array}{l}10 / 20 \\
(50)\end{array}$ & 0.018 & 5.7 & $\begin{array}{l}1.3- \\
25.6\end{array}$ & 0.024 \\
\hline \multirow[t]{2}{*}{ Gender } & male & $\begin{array}{l}2 / 17 \\
(11.8)\end{array}$ & $\begin{array}{l}8 / 15 \\
(53.3)\end{array}$ & 0.011 & 8.6 & $\begin{array}{l}1.4- \\
51.4\end{array}$ & 0.019 \\
\hline & female & $\begin{array}{l}1 / 3 \\
\text { (33.3) }\end{array}$ & $\begin{array}{l}2 / 5 \\
(40)\end{array}$ & 0.85 & 1.3 & $\begin{array}{l}0.1- \\
26.6\end{array}$ & 0.851 \\
\hline \multirow[t]{2}{*}{ Age } & $\leq 55$ years & $\begin{array}{l}2 / 9 \\
(22.2)\end{array}$ & $\begin{array}{l}6 / 11 \\
(54.5)\end{array}$ & 0.142 & 4.2 & $\begin{array}{l}0.6- \\
30.1\end{array}$ & 0.153 \\
\hline & $>55$ years & $\begin{array}{l}1 / 11 \\
(9.1)\end{array}$ & $\begin{array}{l}4 / 9 \\
(44.4)\end{array}$ & 0.069 & 8 & $\begin{array}{l}0.7- \\
91.8\end{array}$ & 0.095 \\
\hline \multirow[t]{2}{*}{ Immunosuppression } & no & $\begin{array}{l}2 / 17 \\
(11.8)\end{array}$ & $\begin{array}{l}7 / 15 \\
(46.7)\end{array}$ & 0.028 & 6.6 & $\begin{array}{l}1.1- \\
39.3\end{array}$ & 0.039 \\
\hline & yes & $\begin{array}{l}1 / 3 \\
(33.3)\end{array}$ & $\begin{array}{l}3 / 5 \\
(60)\end{array}$ & 0.465 & 3 & $\begin{array}{l}0.2- \\
59.9\end{array}$ & 0.472 \\
\hline \multirow[t]{2}{*}{ Onset } & ambulatory & $\begin{array}{l}1 / 13 \\
(7.7)\end{array}$ & $\begin{array}{l}8 / 13 \\
(61.5)\end{array}$ & 0.004 & 19.2 & $\begin{array}{l}1.9- \\
196.5\end{array}$ & 0.013 \\
\hline & hospital & $\begin{array}{l}2 / 7 \\
(28.6)\end{array}$ & $\begin{array}{l}2 / 7 \\
(28.6)\end{array}$ & 1 & 1 & $\begin{array}{l}0.1- \\
10.2\end{array}$ & 1 \\
\hline \multirow[t]{2}{*}{ Pathogen } & gram + & $\begin{array}{l}1 / 6 \\
(16.7)\end{array}$ & $\begin{array}{l}1 / 6 \\
(16.7)\end{array}$ & 1 & 1 & $\begin{array}{l}0.05- \\
20.8\end{array}$ & 1 \\
\hline & gram - & $\begin{array}{l}3 / 8 \\
(37.5)\end{array}$ & $\begin{array}{l}4 / 4 \\
(100)\end{array}$ & 0.038 & - & - & - \\
\hline \multirow[t]{2}{*}{ Focus } & lung & $\begin{array}{l}1 / 12 \\
(8.3)\end{array}$ & $\begin{array}{l}7 / 13 \\
(53.8)\end{array}$ & 0.015 & 12.8 & $\begin{array}{l}1.3- \\
130.5\end{array}$ & 0.031 \\
\hline & abdomen & $\begin{array}{l}2 / 6 \\
(33.3)\end{array}$ & $\begin{array}{l}2 / 6 \\
(33.3)\end{array}$ & 1 & 1 & $\begin{array}{l}0.1- \\
11\end{array}$ & 1 \\
\hline \multirow[t]{2}{*}{ RRT } & no RRT & $\begin{array}{l}1 / 6 \\
(16.7)\end{array}$ & $\begin{array}{l}4 / 8 \\
(50)\end{array}$ & 0.198 & 5 & $\begin{array}{l}0.4- \\
64.4\end{array}$ & 0.217 \\
\hline & RRT & $\begin{array}{l}2 / 14 \\
(14.3)\end{array}$ & $\begin{array}{l}6 / 12 \\
(50)\end{array}$ & 0.049 & 6 & $\begin{array}{l}0.9- \\
39.2\end{array}$ & 0.061 \\
\hline \multirow[t]{2}{*}{ Norepinephrine dose } & $\leq 0.6 \mu \mathrm{g} / \mathrm{kg} / \mathrm{min}$ & $\begin{array}{l}2 / 11 \\
(18.2)\end{array}$ & $\begin{array}{l}2 / 10 \\
(20)\end{array}$ & 0.916 & 1.1 & $\begin{array}{l}0.1- \\
9.9\end{array}$ & 0.916 \\
\hline & $>0.6 \mu \mathrm{g} / \mathrm{kg} / \mathrm{min}$ & $1 / 9$ & $8 / 10$ & 0.003 & 32 & $2.4-$ & 0.009 \\
\hline
\end{tabular}


(11.1) (80)

427.7

\begin{tabular}{|c|c|c|c|c|c|c|c|}
\hline VIS Score & $\leq 61$ points & $\begin{array}{l}2 / 10 \\
(20)\end{array}$ & $\begin{array}{l}3 / 11 \\
(27.3)\end{array}$ & 0.696 & 1.5 & $\begin{array}{l}0.2- \\
11.5\end{array}$ & 0.697 \\
\hline & $>61$ points & $\begin{array}{l}1 / 10 \\
(10)\end{array}$ & $\begin{array}{l}7 / 9 \\
(77.8)\end{array}$ & 0.003 & 31.5 & $\begin{array}{l}2.4- \\
422.3\end{array}$ & 0.009 \\
\hline \multirow[t]{2}{*}{ Lactate } & $\leq 4 \mathrm{mmol} / \mathrm{l}$ & $\begin{array}{l}3 / 10 \\
(30)\end{array}$ & $\begin{array}{l}6 / 10 \\
(60)\end{array}$ & 0.178 & 3.5 & $\begin{array}{l}0.6- \\
22.3\end{array}$ & 0.185 \\
\hline & $>4 \mathrm{mmol} / \mathrm{l}$ & $\begin{array}{l}0 / 10 \\
(0)\end{array}$ & $\begin{array}{l}4 / 10 \\
(40)\end{array}$ & 0.025 & - & - & - \\
\hline
\end{tabular}

\begin{tabular}{|c|c|c|c|c|c|c|c|}
\hline \multirow[t]{2}{*}{ p02/FiO2 } & $\geq 150 \mathrm{mmHg}$ & $\begin{array}{l}2 / 12 \\
(16.7)\end{array}$ & $\begin{array}{l}2 / 9 \\
(22.2)\end{array}$ & 0.748 & 1.4 & $\begin{array}{l}0.2- \\
12.7\end{array}$ & 0.749 \\
\hline & $<150 \mathrm{mmHg}$ & $\begin{array}{l}1 / 8 \\
(12.5)\end{array}$ & $\begin{array}{l}8 / 11 \\
(72.7)\end{array}$ & 0.009 & 18.7 & $\begin{array}{l}1.6- \\
222.9\end{array}$ & 0.021 \\
\hline \multirow[t]{2}{*}{ SOFA-Score } & $\leq 16$ points & $\begin{array}{l}2 / 8 \\
(25)\end{array}$ & $\begin{array}{l}5 / 12 \\
(41.7)\end{array}$ & 0.444 & 2.1 & $\begin{array}{l}0.3- \\
15.4\end{array}$ & 0.448 \\
\hline & $>16$ points & $\begin{array}{l}1 / 12 \\
(8.3)\end{array}$ & $\begin{array}{l}5 / 8 \\
(62.5)\end{array}$ & 0.01 & 18.3 & $\begin{array}{l}1.5- \\
222.9\end{array}$ & 0.022 \\
\hline \multirow[t]{4}{*}{$\begin{array}{l}\text { Organ Specific } \\
\text { Failure }\end{array}$} & $\begin{array}{l}\operatorname{Resp}(\mathrm{pO} 2 / \mathrm{FiO} 2<300 \\
\mathrm{mmHg})\end{array}$ & $\begin{array}{l}3 / 19 \\
(15.8)\end{array}$ & $\begin{array}{l}10 / 20 \\
(50)\end{array}$ & 0.023 & 5.3 & $\begin{array}{l}1.2- \\
24.2\end{array}$ & 0.03 \\
\hline & $\begin{array}{l}\text { Coag }(\text { Thrombocytes } \\
\left.<100 \times 10^{\wedge} 3 / \mu \mathrm{l}\right)\end{array}$ & $\begin{array}{l}1 / 10 \\
(10)\end{array}$ & $\begin{array}{l}4 / 9 \\
(44.4)\end{array}$ & 0.089 & 7.2 & $\begin{array}{l}0.6- \\
83.3\end{array}$ & 0.114 \\
\hline & Liver (Bili > 32 $\mu \mathrm{mol} / \mathrm{l})$ & $\begin{array}{l}2 / 11 \\
(18.2)\end{array}$ & $\begin{array}{l}2 / 5 \\
(40)\end{array}$ & 0.35 & 3 & $\begin{array}{l}0.3- \\
31.6\end{array}$ & 0.361 \\
\hline & $\begin{array}{l}\text { Renal (Crea > } \\
170 \mu \mathrm{mol} / \mathrm{l})\end{array}$ & $\begin{array}{l}3 / 16 \\
(18.8)\end{array}$ & $\begin{array}{l}9 / 16 \\
(56.3)\end{array}$ & 0.028 & 5.6 & $\begin{array}{l}1.1- \\
27.5\end{array}$ & 0.035 \\
\hline \multirow[t]{2}{*}{ CRP } & $\leq 297 \mathrm{mg} / \mathrm{l}$ & $\begin{array}{l}1 / 10 \\
(10)\end{array}$ & $\begin{array}{l}4 / 9 \\
(44.4)\end{array}$ & 0.089 & 7.2 & $\begin{array}{l}0.6- \\
83.3\end{array}$ & 0.114 \\
\hline & $>297 \mathrm{mg} / \mathrm{l}$ & $\begin{array}{l}2 / 10 \\
(20)\end{array}$ & $\begin{array}{l}6 / 10 \\
(60)\end{array}$ & 0.068 & 6 & $\begin{array}{l}0.8- \\
44.4\end{array}$ & 0.079 \\
\hline \multirow[t]{2}{*}{ РCT } & $\leq 30 \mu \mathrm{g} / \mathrm{l}$ & $\begin{array}{l}1 / 8 \\
(12.5)\end{array}$ & $\begin{array}{l}5 / 12 \\
(41.7)\end{array}$ & 0.163 & 5 & $\begin{array}{l}0.5- \\
54.5\end{array}$ & 0.187 \\
\hline & $>30 \mu \mathrm{g} / \mathrm{l}$ & $\begin{array}{l}2 / 12 \\
(16.7)\end{array}$ & $\begin{array}{l}5 / 8 \\
(62.5)\end{array}$ & 0.035 & 8.3 & $\begin{array}{l}1.1- \\
67.1\end{array}$ & 0.046 \\
\hline \multirow[t]{2}{*}{ Leucocytes } & $\leq 17\left(10^{\wedge} 3 / \mu \mathrm{l}\right)$ & $\begin{array}{l}1 / 14 \\
(7.1)\end{array}$ & $\begin{array}{l}4 / 9 \\
(44.4)\end{array}$ & 0.034 & 10.4 & $\begin{array}{l}0.9- \\
117.2\end{array}$ & 0.058 \\
\hline & > $17\left(10^{\wedge} 3 / \mu \mathrm{l}\right)$ & $\begin{array}{l}2 / 6 \\
(33.3)\end{array}$ & $\begin{array}{l}6 / 11 \\
(54.5)\end{array}$ & 0.402 & 2.4 & $\begin{array}{l}0.3- \\
19\end{array}$ & 0.407 \\
\hline
\end{tabular}


$\mathrm{BMI}=$ Body mass index, $\mathrm{CRP}=\mathrm{C}$-reactive protein, $\mathrm{NE}=$ Norepinephrine, $\mathrm{OR}=$ Odds ratio, $\mathrm{PCT}=$ Procalcitonin, RRT $=$ Renal replacement therapy, $S O C=$ Standard of Care, SOFA $=$ Sequential Organ Failure Assessment, TPE = Therapeutic plasma exchange, VIS = Vasoactive-Inotropic Score, WBC = White blood cell count

Table 4: 28-day Mortality - Subgroup Analysis 
Characteristic (at randomisation)

\begin{tabular}{|c|c|c|c|c|c|c|c|}
\hline - & - & SOC & TPE & $\mathbf{p}$ & HR & $95 \%-\mathrm{Cl}$ & p \\
\hline All & - & $\begin{array}{l}10 / 20 \\
(50)\end{array}$ & $\begin{array}{l}8 / 20 \\
(40)\end{array}$ & 0.437 & 0.702 & $\begin{array}{l}0.277- \\
1.783\end{array}$ & 0.457 \\
\hline \multirow[t]{2}{*}{ Gender } & male & $\begin{array}{l}8 / 17 \\
(47.1)\end{array}$ & $\begin{array}{l}5 / 15 \\
(33.3)\end{array}$ & 0.298 & 0.571 & $\begin{array}{l}0.186- \\
1.755\end{array}$ & 0.328 \\
\hline & female & $\begin{array}{l}2 / 3 \\
(66.6)\end{array}$ & $\begin{array}{l}3 / 5 \\
(60)\end{array}$ & 0.715 & 1.399 & $\begin{array}{l}0.229- \\
8.547\end{array}$ & 0.716 \\
\hline \multirow[t]{2}{*}{ Age } & $\leq 55$ years & $\begin{array}{l}3 / 9 \\
(33.3)\end{array}$ & $\begin{array}{l}4 / 11 \\
(36.4)\end{array}$ & 0.936 & 1.063 & $\begin{array}{l}0.237- \\
4.766\end{array}$ & 0.936 \\
\hline & $>55$ years & $\begin{array}{l}7 / 11 \\
(63.6)\end{array}$ & $\begin{array}{l}4 / 9 \\
(44.4)\end{array}$ & 0.381 & 0.601 & $\begin{array}{l}0.175- \\
2.058\end{array}$ & 0.417 \\
\hline \multirow[t]{2}{*}{ Immunosuppression } & no & $\begin{array}{l}9 / 17 \\
(52.9)\end{array}$ & $\begin{array}{l}5 / 15 \\
(33.3)\end{array}$ & 0.274 & 0.562 & $\begin{array}{l}0.188- \\
1.68\end{array}$ & 0.303 \\
\hline & yes & $\begin{array}{l}1 / 3 \\
(33.3)\end{array}$ & $\begin{array}{l}3 / 5 \\
(60)\end{array}$ & 0.678 & 1.611 & $\begin{array}{l}0.166- \\
15.603\end{array}$ & 0.681 \\
\hline \multirow[t]{2}{*}{ Onset } & ambulatory & $\begin{array}{l}6 / 13 \\
(46.2)\end{array}$ & $\begin{array}{l}5 / 13 \\
(38.5)\end{array}$ & 0.636 & 0.759 & $\begin{array}{l}0.231- \\
2.491\end{array}$ & 0.649 \\
\hline & hospital & $\begin{array}{l}4 / 7 \\
(57.1)\end{array}$ & $\begin{array}{l}3 / 7 \\
(42.9)\end{array}$ & 0.532 & 0.631 & $\begin{array}{l}0.14- \\
2.845\end{array}$ & 0.549 \\
\hline \multirow[t]{2}{*}{ Pathogen } & gram + & $\begin{array}{l}2 / 6 \\
(33.3)\end{array}$ & $\begin{array}{l}2 / 6 \\
(33.3)\end{array}$ & 1 & 1 & $\begin{array}{l}0.141- \\
7.099\end{array}$ & 1 \\
\hline & gram - & $\begin{array}{l}2 / 5 \\
(40)\end{array}$ & $\begin{array}{l}3 / 7 \\
(42.9)\end{array}$ & 0.889 & 0.882 & $\begin{array}{l}0.147- \\
5.296\end{array}$ & 0.891 \\
\hline \multirow[t]{2}{*}{ Focus } & lung & $\begin{array}{l}5 / 12 \\
(41.7)\end{array}$ & $\begin{array}{l}2 / 13 \\
(15.4)\end{array}$ & 0.089 & 0.297 & $\begin{array}{l}0.057- \\
1.538\end{array}$ & 0.148 \\
\hline & abdomen & $\begin{array}{l}4 / 6 \\
(66.7)\end{array}$ & $\begin{array}{l}5 / 6 \\
(83.3)\end{array}$ & 0.627 & 1.575 & $\begin{array}{l}0.411- \\
6.034\end{array}$ & 0.507 \\
\hline \multirow[t]{2}{*}{ RRT } & no RRT & $\begin{array}{l}3 / 6 \\
(50)\end{array}$ & $\begin{array}{l}2 / 8 \\
(25)\end{array}$ & 0.329 & 0.425 & $\begin{array}{l}0.071- \\
2.56\end{array}$ & 0.351 \\
\hline & RRT & $\begin{array}{l}7 / 14 \\
(50)\end{array}$ & $\begin{array}{l}6 / 12 \\
(50)\end{array}$ & 0.887 & 0.927 & $\begin{array}{l}0.311- \\
2.763\end{array}$ & 0.892 \\
\hline \multirow[t]{2}{*}{ Norepinephrine dose } & $\leq 0.6 \mu \mathrm{g} / \mathrm{kg} / \mathrm{min}$ & $\begin{array}{l}6 / 11 \\
(54.5)\end{array}$ & $\begin{array}{l}2 / 10 \\
(20)\end{array}$ & 0.099 & 0.294 & $\begin{array}{l}0.059- \\
1.465\end{array}$ & 0.135 \\
\hline & $>0.6 \mu \mathrm{g} / \mathrm{kg} / \mathrm{min}$ & $\begin{array}{l}4 / 9 \\
(44.4)\end{array}$ & $\begin{array}{l}6 / 10 \\
(60)\end{array}$ & 0.634 & 1.349 & $\begin{array}{l}0.38- \\
4.794\end{array}$ & 0.644 \\
\hline
\end{tabular}

No. of

events/total

no. (\%)

/

$3 / 9$

$7 / 11 \quad 4 / 9$

$9 / 17$

$9 / 17$

$5 / 15$

(60)

$5 / 13$

4/7

$3 / 7$

Cox Regression 


\begin{tabular}{|c|c|c|c|c|c|c|c|}
\hline VIS Score & $\leq 61$ points & $\begin{array}{l}5 / 10 \\
(50)\end{array}$ & $\begin{array}{l}3 / 11 \\
(27.3)\end{array}$ & 0.294 & 0.485 & $\begin{array}{l}0.116- \\
2.036\end{array}$ & 0.323 \\
\hline & $>61$ points & $\begin{array}{l}5 / 10 \\
(50)\end{array}$ & $\begin{array}{l}5 / 9 \\
(55.6)\end{array}$ & 0.943 & 0.956 & $\begin{array}{l}0.276- \\
3.318\end{array}$ & 0.944 \\
\hline \multirow[t]{2}{*}{ Lactate } & $\leq 4 \mathrm{mmol} / \mathrm{l}$ & $\begin{array}{l}3 / 10 \\
(30)\end{array}$ & $\begin{array}{l}4 / 10 \\
(40)\end{array}$ & 0.594 & 1.494 & $\begin{array}{l}0.334- \\
6.691\end{array}$ & 0.6 \\
\hline & $>4 \mathrm{mmol} / \mathrm{l}$ & $\begin{array}{l}7 / 10 \\
(70)\end{array}$ & $\begin{array}{l}4 / 10 \\
(40)\end{array}$ & 0.093 & 0.384 & $\begin{array}{l}0.111- \\
1.335\end{array}$ & 0.132 \\
\hline \multirow[t]{2}{*}{ p02/FiO2 } & $\geq 150 \mathrm{mmHg}$ & $\begin{array}{l}7 / 12 \\
(58.3)\end{array}$ & $\begin{array}{l}2 / 9 \\
(22.2)\end{array}$ & 0.116 & 0.312 & $\begin{array}{l}0.065- \\
1.505\end{array}$ & 0.147 \\
\hline & $<150 \mathrm{mmHg}$ & $\begin{array}{l}3 / 8 \\
(37.5)\end{array}$ & $\begin{array}{l}6 / 11 \\
(54.5)\end{array}$ & 0.655 & 1.354 & $\begin{array}{l}0.338- \\
5.433\end{array}$ & 0.669 \\
\hline \multirow[t]{2}{*}{ SOFA-Score } & $\leq 16$ points & $\begin{array}{l}3 / 8 \\
(37.5)\end{array}$ & $\begin{array}{l}2 / 12 \\
(16.7)\end{array}$ & 0.282 & 0.411 & $\begin{array}{l}0.068- \\
2.472\end{array}$ & 0.331 \\
\hline & $>16$ points & $\begin{array}{l}7 / 12 \\
(58.3)\end{array}$ & $\begin{array}{l}6 / 8 \\
(75)\end{array}$ & 0.618 & 1.309 & $\begin{array}{l}0.436- \\
3.928\end{array}$ & 0.631 \\
\hline \multirow[t]{4}{*}{$\begin{array}{l}\text { Organ Specific } \\
\text { Failure }\end{array}$} & $\begin{array}{l}\operatorname{Resp}(\mathrm{pO} 2 / \mathrm{FiO} 2 \\
<300 \mathrm{mmHg})\end{array}$ & $\begin{array}{l}10 / 19 \\
(52.6)\end{array}$ & $\begin{array}{l}8 / 20 \\
(40)\end{array}$ & 0.349 & 0.654 & $\begin{array}{l}0.258- \\
1.661\end{array}$ & 0.372 \\
\hline & $\begin{array}{l}\text { Coag } \\
\text { (Thrombocytes < } \\
\left.100 \times 10^{\wedge} 3 / \mu \mathrm{l}\right)\end{array}$ & $\begin{array}{l}5 / 10 \\
(50)\end{array}$ & $\begin{array}{l}4 / 9 \\
(44.4)\end{array}$ & 0.758 & 0.815 & $\begin{array}{l}0.218- \\
3.043\end{array}$ & 0.761 \\
\hline & $\begin{array}{l}\text { Liver (Bili > } \\
32 \mu \mathrm{mol} / \mathrm{l})\end{array}$ & $\begin{array}{l}6 / 11 \\
(54.5)\end{array}$ & $\begin{array}{l}4 / 5 \\
(80)\end{array}$ & 0.519 & 1.501 & $\begin{array}{l}0.416- \\
5.41\end{array}$ & 0.535 \\
\hline & $\begin{array}{l}\text { Renal (Crea > } \\
170 \mu \mathrm{mol} / \mathrm{l})\end{array}$ & $\begin{array}{l}9 / 16 \\
(56.3)\end{array}$ & $\begin{array}{l}6 / 16 \\
(37.5)\end{array}$ & 0.239 & 0.555 & $\begin{array}{l}0.197- \\
1.563\end{array}$ & 0.265 \\
\hline \multirow[t]{2}{*}{ CRP } & $\leq 297 \mathrm{mg} / \mathrm{l}$ & $\begin{array}{l}7 / 10 \\
(70)\end{array}$ & $\begin{array}{l}4 / 9 \\
(44.4)\end{array}$ & 0.275 & 0.529 & $\begin{array}{l}0.154- \\
1.817\end{array}$ & 0.312 \\
\hline & > 297mg/l & $\begin{array}{l}3 / 10 \\
(30)\end{array}$ & $\begin{array}{l}4 / 10 \\
(40)\end{array}$ & 0.771 & 1.247 & $\begin{array}{l}0.279- \\
5.577\end{array}$ & 0.773 \\
\hline \multirow[t]{2}{*}{ РCT } & $\leq 30 \mu \mathrm{g} / \mathrm{l}$ & $\begin{array}{l}5 / 8 \\
(62.5)\end{array}$ & $\begin{array}{l}4 / 12 \\
(33.3)\end{array}$ & 0.071 & 0.374 & $\begin{array}{l}0.099- \\
1.408\end{array}$ & 0.146 \\
\hline & $>30 \mu \mathrm{g} / \mathrm{l}$ & $\begin{array}{l}5 / 12 \\
(41.7)\end{array}$ & $\begin{array}{l}4 / 8 \\
(50)\end{array}$ & 0.729 & 1.251 & $\begin{array}{l}0.335- \\
4.668\end{array}$ & 0.739 \\
\hline \multirow[t]{2}{*}{ Leucocytes } & $\leq 17\left(10^{\wedge} 3 / \mu \mathrm{l}\right)$ & $\begin{array}{l}6 / 14 \\
(42.9)\end{array}$ & $\begin{array}{l}4 / 9 \\
(44.4)\end{array}$ & 0.973 & 0.98 & $\begin{array}{l}0.276- \\
3.477\end{array}$ & 0.975 \\
\hline & $>17\left(10^{\wedge} 3 / \mu \mathrm{l}\right)$ & $\begin{array}{l}4 / 6 \\
(66.7)\end{array}$ & $\begin{array}{l}4 / 11 \\
(36.4)\end{array}$ & 0.160 & 0.384 & $\begin{array}{l}0.095- \\
1.551\end{array}$ & 0.179 \\
\hline
\end{tabular}

\section{Figures}




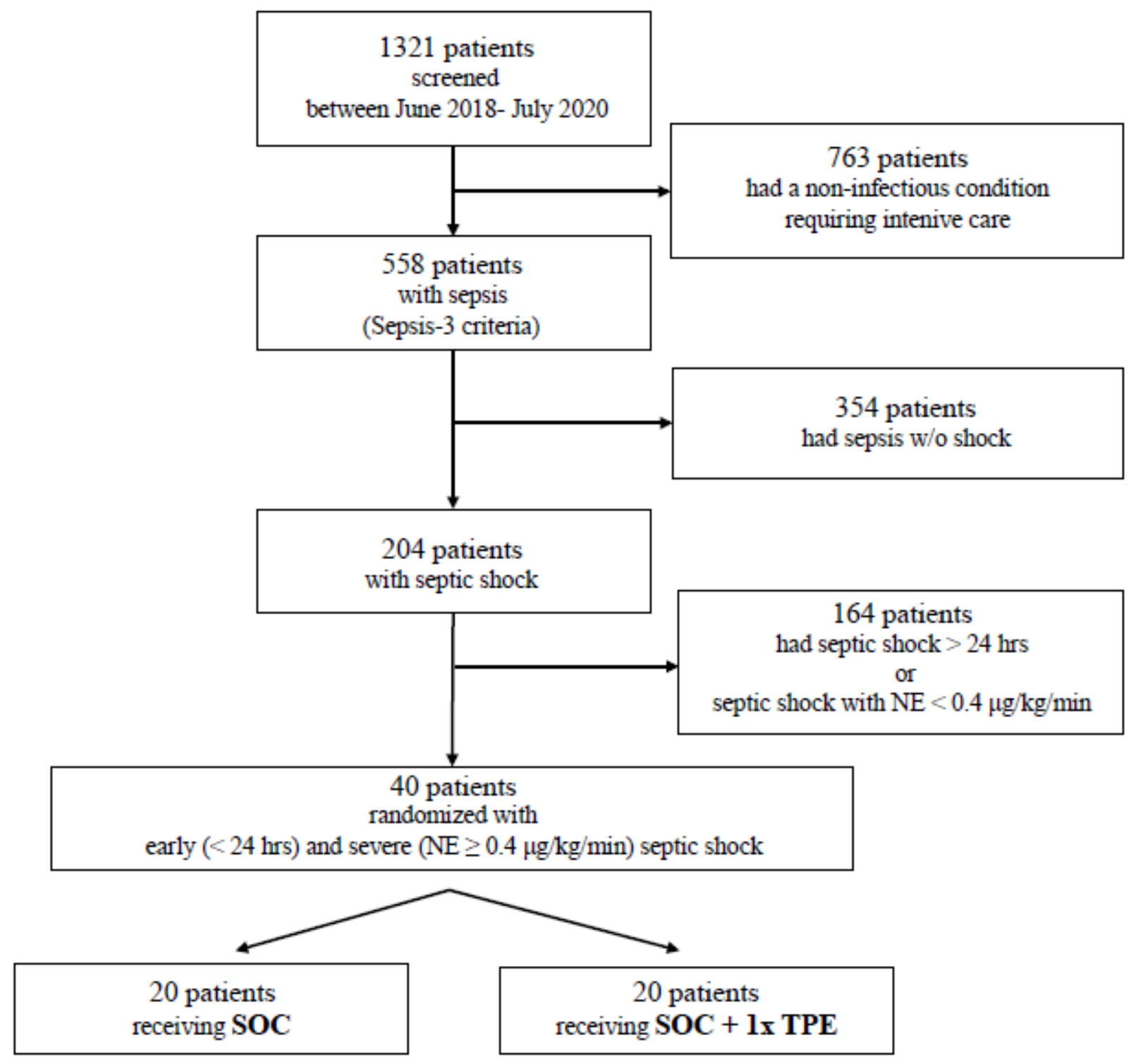

Figure 1

Flow chart of study participants. Shown are screening, enrollment and randomization of patients. Inclusion criteria were early ( $<24 \mathrm{hrs}$ ) and severe (Norepinephrine (NE) dose $\geq 0.4 \mu \mathrm{g} / \mathrm{kg} / \mathrm{min}$ despite adequate fluid resuscitation) septic shock. The study compared Standard of Care (SOC) to SOC + a singular Therapeutic Plasma Exchange (TPE), performed immediately following 1:1 envelope-based randomization. 

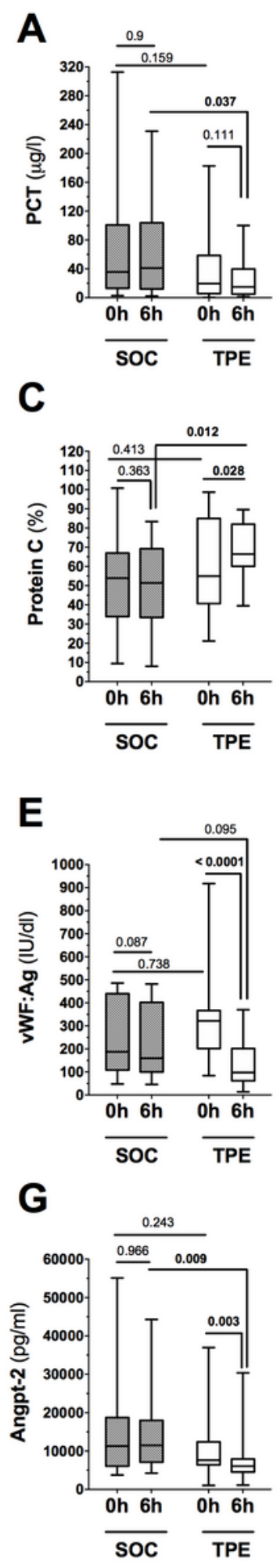
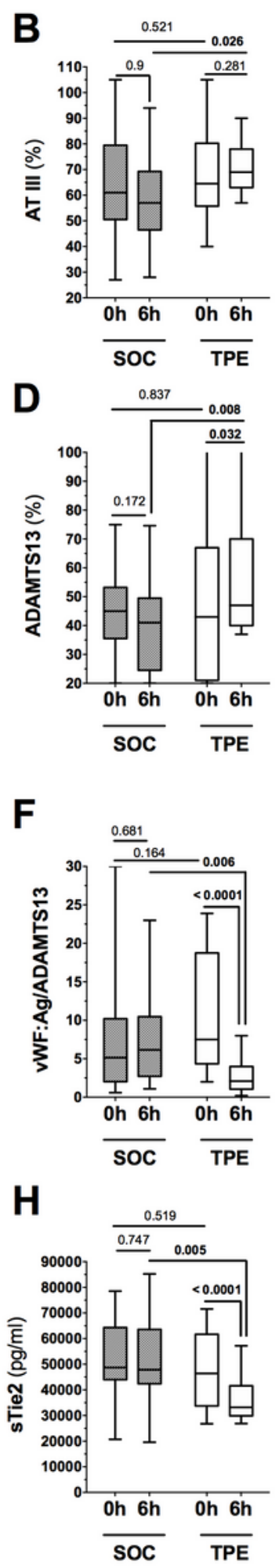

\section{Figure 2}

Secondary biochemical endpoints. Box and whisker blots showing (A) Procalcitonin (PCT), (B) Antithrombin-III (AT-III), C) Protein C, (D) A disintegrin and metalloprotease with thrombospondin-1-like domains 13 (ADAMTS13), (E) von-Willebrand factor Antigen (vWF:Ag), (F) vWF:Ag/ADAMTS13 ratio, (G) Angiopoietin-2 (Angpt-2), (H) soluble receptor of tyrosine kinase with immunoglobulin-like and EGF-like domains (sTie-2) for patients receiving Standard of Care Treatment (SOC) as well as patients receiving 
additive Therapeutic Plasma Exchange (TPE). Compared are results both at randomization and 6 hrs after randomization and between group differences.

\section{Odds ratio $(95 \% \mathrm{CI})$}

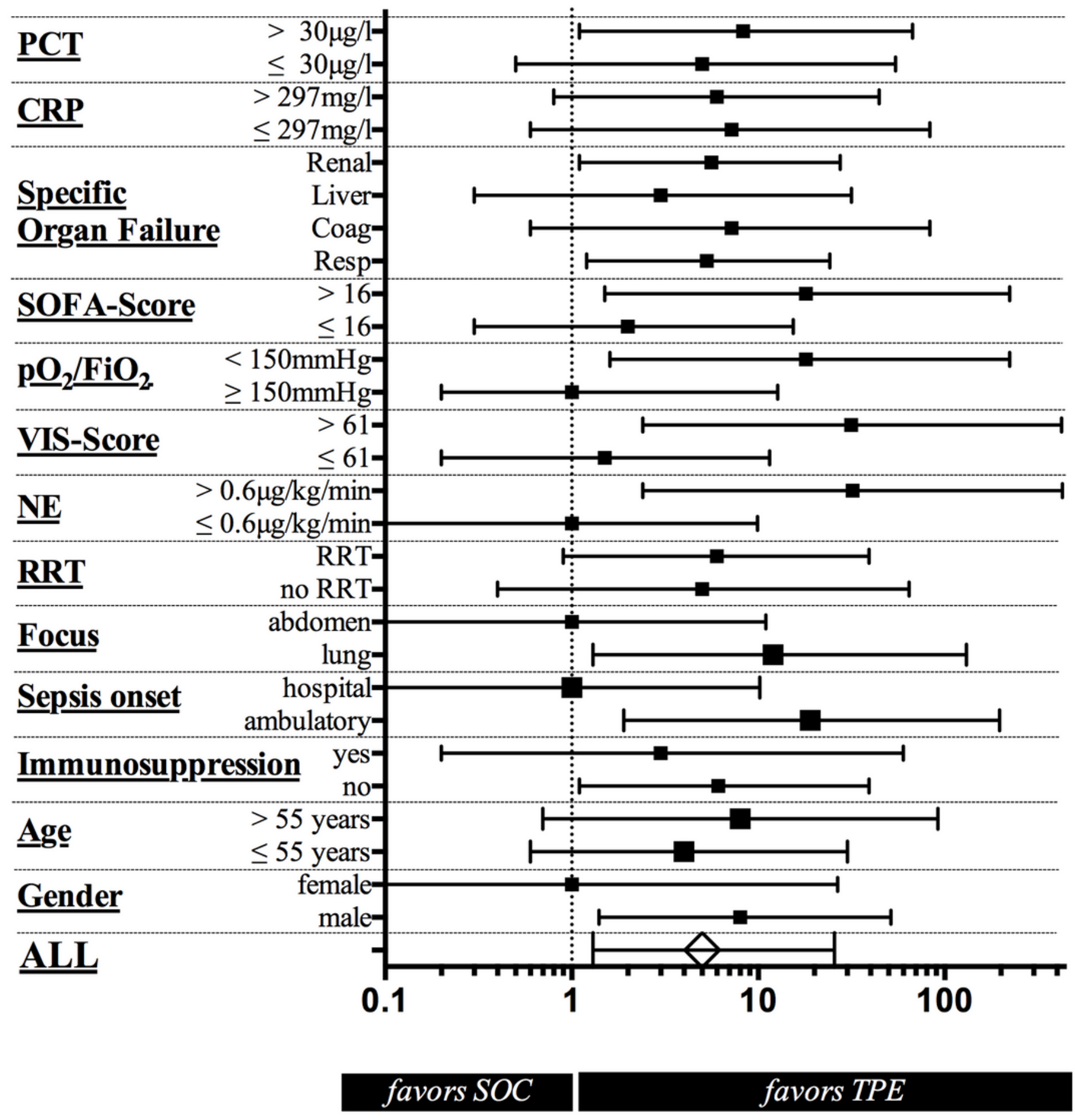

Figure 3

Subgroup analysis for primary endpoint Norepinephrine dose reduction $>50 \%$ from baseline. Forest plot demonstrating differences in achieving the endpoint Norepinephrine dose reduction $>50 \%$ from baseline, 
for Standard of Care (SOC) and Therapeutic Plasma Exchange (TPE) group, dependent on baseline demographic and clinical characteristics.

\section{Hazard ratio $(95 \% \mathrm{CI})$}

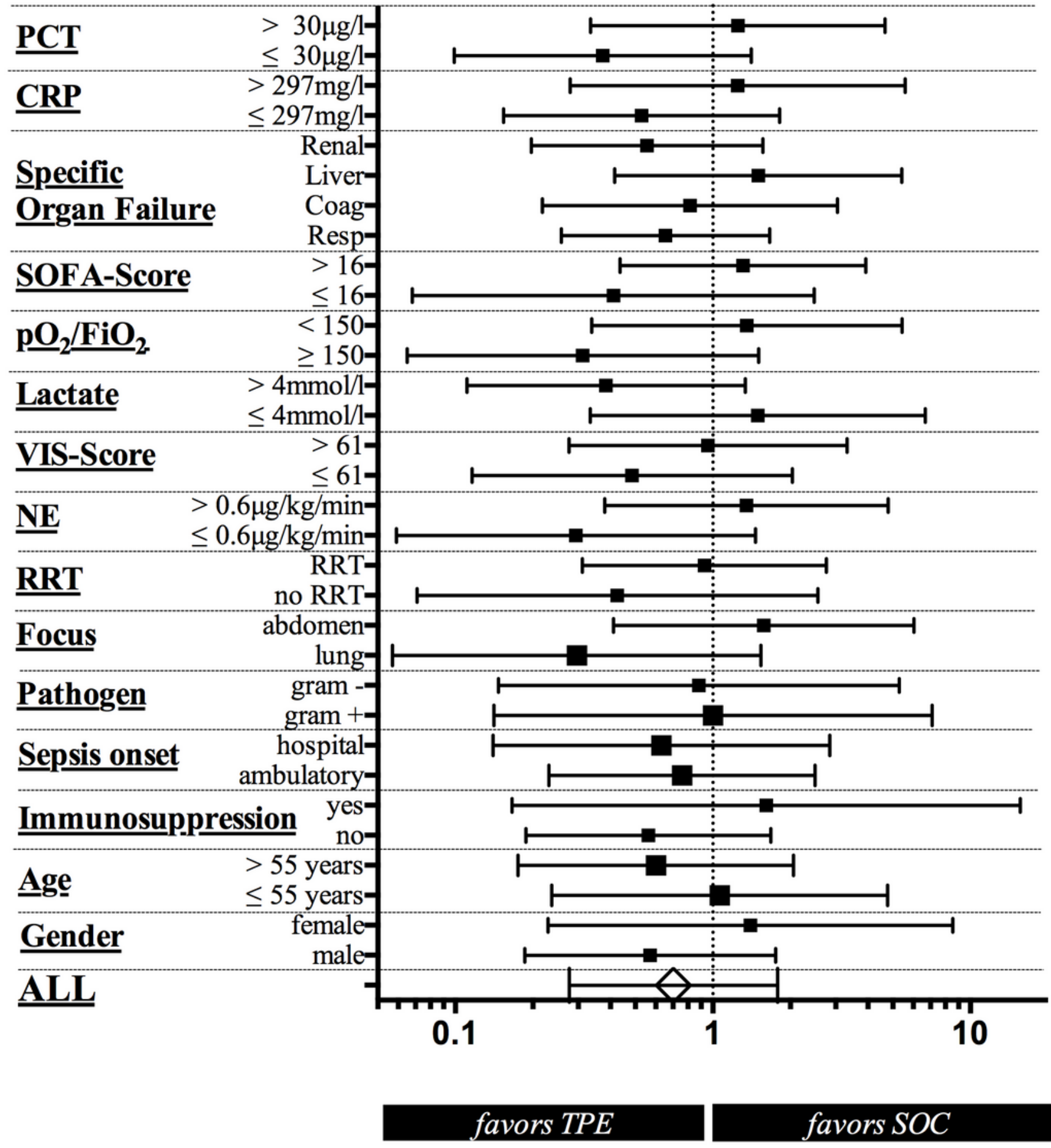

Figure 4

Subgroup analysis for secondary endpoint 28-day mortality. Forest plot demonstrating differences in the endpoint 28-day mortality for Standard of Care (SOC) and Therapeutic Plasma Exchange (TPE) group, dependent on baseline demographic and clinical characteristics. 